\title{
INFLUENCE OF EXTRACT FROM SHOOTS OF TAXUS BACCATA VAR. ELEGANTISSIMA ON ULTRASTRUCTURE AND TUBULIN CYTOSKELETON OF MERISTEMATIC CELLS OF ALLIUM CEPA L. ROOTS
}

\author{
AgNiESZKa MaJewsKa ${ }^{1}$, MirosŁaWA Furmanowa ${ }^{2}$, KAZIMIERZ GŁOWNIAK ${ }^{3}$, \\ JOANNA GUZEWSKA ${ }^{2}$, ALICJA ZOBEL ${ }^{4}$, MIECZYSŁAW KuRAŚ ${ }^{1}$ \\ ${ }^{1}$ Department of Plant Morphogenesis, Warsaw University \\ Miecznikowa 2, 02-067 Warsaw, Poland \\ ${ }^{2}$ Department of Biology and Pharmaceutical Botany, Medical University of Warsaw \\ Banacha 1, 02-097 Warsaw, Poland \\ ${ }^{3}$ Department of Pharmacognosy, Medical Academy \\ Peowiaków 12, 20-007 Lublin, Poland \\ ${ }^{4}$ Department of Chemistry, Trent University, Peterborough, Ontario \\ Canada, K9J 7B8
}

(Received: February 18, 2002. Accepted: June 20, 2002)

\begin{abstract}
We investigated the influence of extract from Taxus baccata var. Elegantissima (TbE) shoots in 1:8 dilution, containing paclitaxel in concentration of $81,6 \mu \mathrm{g} / \mathrm{g}$ fresh mass on ultrastructure and tubulin cytoskeleton of meristematic cells of Allium cepa $\mathrm{L}$. root tips. Incubation time 3, 6, 12 and $24 \mathrm{~h}$ was followed with postincubation in water for 12 and $24 \mathrm{~h}$. During shorter incubation (till $12 \mathrm{~h}$ ) the surface of the cell nuclei decreased and chromatin became condensed (in comparison to control) but after $24 \mathrm{~h}$ the average surface increased and chromatin condensation decreased. In the course of incubation the average size of plastids and vacuoles increased. Moreover, after treatment mitochondria and plastids showed degradation of ultrastructure, which was reversed after $12 \mathrm{~h}$ of postincubation.

Immunocytochemical assays demonstrated that in the course of incubation in the TbE extract, the tubulin cytoskeleton became partially disorganised. In most interphase cells, cortical microtubules (MTs) lost their oval transverse orientation. The preprophase band (PPB) position in the cell was often asymmetrical. The MTs array of the karyokinetic spindle and phragmoplast was also disturbed. These alterations were completely reversed during postincubation.
\end{abstract}

KEYWORDS: Taxus baccata var. Elegantissima, extract, paclitaxel, ultrastructure, tubulin cytoskeleton.

\section{INTRODUCTION}

Paclitaxel obtained from extract of bark of the Pacific yew (Taxus brevifolia) (Wani 1971) is introduced to therapy of several malignancies (e.g. of the breast, lung and ovary) as the commercially available drug $\mathrm{Taxol}^{\circledR}$. It binds with the $\beta$-tubulin subunit (Rao et al. 1994) leading to stabilisation of MTs and reduction of the critical level of tubulin concentration in the cytoplasm (Schiff and Horwitz 1980). The MTs stabilisation leads to inhibition of cell divisions as the cell cycle becomes arrested in the late G2/M phase (Schiff and Horwitz 1980). Stabilised MTs form untypical arrays seen as bundles and asters (Rowinsky et al. 1988). Ultimately the cell dies as a result of apoptosis (Haldar et al. 1996).
After treatment of paclitaxel also micronuclei are formed and it produces alterations in the shape of the cell nuclei as lobed nuclei (Theodoropolous et al. 1999). This compound affects both intra- and inter-cellular transport as well as secretion of some compounds (Rainey et al. 1985; Long and Fairchild 1994) and modifies the function of the Golgi apparatus (Moortele et al. 1992).

Most studies of paclitaxel have been performed on animal cells, but only few on plant cells. Baluška et al. (1997) in their study of maize root cells demonstrated, that after 24-h treatment with $30-100 \mu \mathrm{M}$ Taxol ${ }^{\circledR}$, MTs became assembled into large bundles and lost their overall transverse orientation. MTs disintegration produced an increase in size of the cell nuclei, chromatin decondensation and activation of cells at the quiescent centre (QC). Both epidermal 
and cortical cells lost their ability to divide and demonstrated chromatin anomalies, lobed nuclei and incomplete formation of the cell wall. Studies by Collings et al. (1998) involving tobacco protoplasts demonstrated that after treatment with $\operatorname{Taxol}^{\otimes}$ the stabilised MTs formed characteristic aggregations of intense fluorescence, which was accompanied by a marked reduction in number of MTs around the cell nucleus. Our earlier studies (Majewska et al. 2000) investigating the effect of Taxus baccata var. Elegantissima extract, containing $81.6 \mu \mathrm{g} / \mathrm{g}$ fresh mass of paclitaxel on the meristematic cells of Allium cepa $\mathrm{L}$. root tips, demonstrated that in the initial phase of incubation altered prophases and c-metaphases became accumulated. After longer incubation mitoses were inhibited and the cell cycle became arrested in the G2/M phase. Additionally, the TbE extract at its highest concentration was lethal for meristematic cells, i.e. produced cell death without resumption of cell divisions during postincubation. On the other hand, the extract did not produce changes in nuclear morphology or lead to the formation of micronuclei typical of paclitaxel action (Long and Fairchild 1994).

Adverse effects due to high toxicity of paclitaxel considerably limit its uses in anti-tumour therapy (Rowinsky et al 1993). The agent cannot be used in high doses over longer periods of time, which lessens its therapeutic efficacy. Many studies have been undertaken to elucidate the mechanism of paclitaxel action. Although the therapeutic questions associated with the use of paclitaxel have been thoroughly investigated, better knowledge is needed of the cytological aspects of its action, especially on plant cells. It is of interest whether the compound cytotoxicity affects in any way the ultrastructure of plant cells. Accordingly, the aim of our study was to investigate the effect of Taxus baccata var. Elegantissima extract on the ultrastructure of cells and tubulin cytoskeleton in a plant experimental system such as the actively dividing meristematic cells of $A$. cepa $\mathrm{L}$. root tips.

\section{MATERIAL AND METHODS}

\section{Extract preparation}

One- and two-year old shoots of Taxus baccata var. 'Elegantissima' (TbE) were obtained from the Botanical Garden, Warsaw University. The extract was prepared from shoots according to the method described by Majewska et al. (2000). The paclitaxel content of the initial extract determined by HPLC was $81.6 \mu \mathrm{g} / \mathrm{g}$ fresh mass. This solution was subsequently diluted with distilled water at a proportion of 1:8. This dilution is considered optimal as it inhibits cell divisions during incubation, but does not cause cell death. Cell divisions are then resumed during postincubation unlike in the case of the lethal concentration, which produces death of cells without subsequent resumption of their divisions (Majewska et al. 2000). The concentration referred to as sublethal was used in the investigations comprising the present study.

\section{Preparation of plant material}

The study was carried out on adventitious root tips of onion (Allium cepa L.), grown according to the method described by Majewska et al. (2000). The onions were obtained from the Plant Genetic Resources Laboratory, Research Institute of Vegetable Crops (Skierniewice, Poland).
When the roots were approximately $4 \mathrm{~cm}(+1 \mathrm{~cm})$ long, they were transferred into the TbE extract (dilution 1:8) for the period of incubation. Next, the roots were rinsed several times in distilled water for $30 \mathrm{~min}$ and left in fresh water (postincubation). In the course of incubation and postincubation, 2-mm long root tips were collected to study their ultrastructure and tubulin cytoskeleton. Only meristematic cells of the cortex were investigated.

\section{Transmission Electron Microscopy procedure and morpho- metric analysis}

Two-mm long root tips collected after 6,12 and $24 \mathrm{~h}$ of incubation and after 6 and $12 \mathrm{~h}$ of postincubation were fixed using the procedure described by Pietrosiuk et al. (1999). It consisted in fixing the plant material in $2.5 \%$ glutaraldehyde $(\mathrm{pH} 7.2)$ and then $1 \% \mathrm{OsO}_{4}$, followed by dehydration in ethyl alcohol and propylene oxide and embedding in a mixture epoxy resins (Epon - Spurr). Sixty eighty $\mathrm{nm}$ sections were prepared using an LKB ultramicrotome (Sweden). Uranyl acetate and lead citrate was used as electron-opaque stains according to Reynolds (1963). The ultrastructure was studied with a transmission electron microscope (TEM) JEOL JEM 100C. Morphometric studies were also performed using micrograph negatives. The measurements and calculations included:

1. The mean number of mitochondria, plastids, vacuoles and dictyosomes on the cell cross section.

2. The length and width of mitochondria, plastids and vacuoles and subsequently their mean surface area calculated according to the formula describing the surface area of an ellipse $\mathrm{P}=\pi \mathrm{ab}$, where $\mathrm{a}$ - organelle length, $\mathrm{b}$ - organelle width.

3. The number of nuclei with condensed chromatin in relation to the total number of all nuclei counted.

In all investigations, 3 root tips from each of 3 onions for each time period were collected. In each tip, 20 meristematic cortical cells were tested.

\section{Measurements of surface area of cell nuclei}

In order to measure the surface area of the cell nuclei, the root tips were collected after 12 and $24 \mathrm{~h}$ of incubation and after $24 \mathrm{~h}$ of postincubation, stained and macerated for 2 $\mathrm{h}$ in $2 \%$ acetoorceine at room temperature and then squashed on microscopic slides. These preparations were used to calculate the surface area of the cell nuclei with a light microscope (Nikon) coupled with a Panasonic GP-KR 222E camera, employing Lucia G software.

One thousand cell nuclei were measured in triplicate for each time period.

\section{Immunocytochemical detection}

In order to analyse the cytoskeleton, the root tips collected after 6 and $12 \mathrm{~h}$ of incubation in the TbE extract and after 2, 4 and $8 \mathrm{~h}$ of postincubation in distilled water, were fixed using the procedure described by Zhang et al. (1996). It consisted in fixing the plant material in $3 \%$ paraformaldehyde, digesting the cell wall with $0.5 \%$ cellulase and removing the membranes with Triton X-100. The material was then squashed on microscopic slides and treated with antibodies: monoclonal antibody against tubulin (mouse anti- $\alpha$-tubulin of the IgG class, Sigma) $(12 \mathrm{~h})$ and secondary FITC (fluorescein isothiocyanate) - labeled antibody (rabbit monoclonal IgG, Sigma) ( $2 \mathrm{~h}$ ). Finally the material 
was embedded in Citifluor with the addition of DAPI (4, 6' diamino-2-phenylindole $2 \mathrm{HCl}) 1 \mu \mathrm{g} / \mathrm{ml}$ to stain the DNA. The tubulin cytoskeleton was observed with an Optiphot 2 fluorescence microscope (Nikon) at excitation wave of 450 $\mathrm{nm}$ and emission spectrum of $520 \mathrm{~nm}$, while the corresponding parameters for the observation of cell nuclei were 365 $\mathrm{nm}$ and $420 \mathrm{~nm}$.

\section{Statistical analysis}

The data were analyzed by one-way analysis of variance (ANOVA), followed by the least-significant StudentNewman-Kelus test, if significance was indicated by the ANOVA.

\section{RESULTS}

\section{Morphometric and ultrastructural changes}

Treatment with the TbE extract produced changes in the surface area of the cell nuclei, in number and surface area of the mitochondria, plastids and vacuoles, as well as in number of dictyosomes in the meristematic cells of A. cepa.

Measurements of the surface area of the cell nuclei following treatment with the TbE extract revealed 3 ranges of cell nuclei sizes: $100-200 \mu \mathrm{m}^{2}, 200-300 \mu \mathrm{m}^{2}$ and $300-400$ $\mu \mathrm{m}^{2}$, of which the proportion changed in the course of incubation and postincubation (Fig. 1). After $12 \mathrm{~h}$ of incubation, the percentage of the nuclei with the smallest surface area increased as compared to control cells, while the percentage of the nuclei with the largest surface area decreased significantly $(\mathrm{p}<0.001)$ by $50 \%$ (Fig. 1). After $24 \mathrm{~h}$ of incubation a reverse phenomenon was observed, the percentage of the nuclei with the smallest surface area decreased, while the percentage of the nuclei with the largest surface area rose significantly $(\mathrm{p}<0.01)$ by $60 \%$ as compared to $12 \mathrm{~h}$ of incubation (Fig. 1). In the course of postincubation the percentage of the nuclei with the smallest surface area rose again, whereas the percentage of the nuclei with the largest surface area was reduced just as after $12 \mathrm{~h}$ of incubation (Fig. 1), so the study cells did not achieve the control status. The percentage of medium-sized cell nuclei remained throughout the experiment at the same level as in control cells, approximately $45 \%$ (Fig. 1).

Morphometric studies demonstrated alterations in the number and surface area of cell organelles, studied following tre-

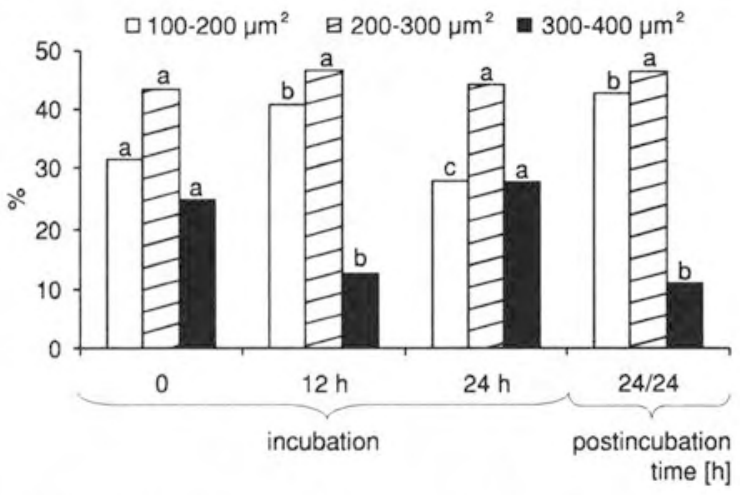

Fig. 1. Proportions (\%) of 3 ranges of cell nucleus sizes during incubation in the TbE extract and postincubation in water. Columns with different letters are significantly different. The method and number of measurements presented in Figs 1-5 are described in „Material and Methods”. atment with the TbE extract and during postincubation (Fig. 2, 3 and 4). During incubation the mean number of mitochondria gradually decreased as compared to control cells $(\mathrm{p}<0.001)$, reaching the lowest number of 21 mitochondria per cell after $24 \mathrm{~h}$ of incubation (Fig. 2). The number of plastids was also reduced after $24 \mathrm{~h}$ of incubation, but only to a slight degree as compared to the drop in the number of mitochondria. After $6 \mathrm{~h}$ of postincubation the mean counts of mitochondria and plastids rose by about $30 \%$ compared to the status after $24 \mathrm{~h}$ of incubation (Fig. 2), while after $12 \mathrm{~h}$ of postincubation their counts only slightly decreased (Fig. 2).

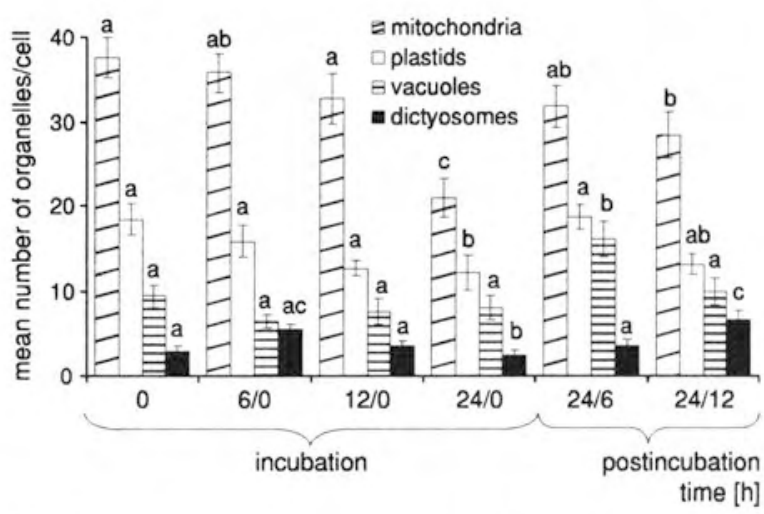

Fig. 2. Mean number of organelles on the cell cross-section during incubation in the TbE extract and postincubation in water. Columns with different letters are significantly different.

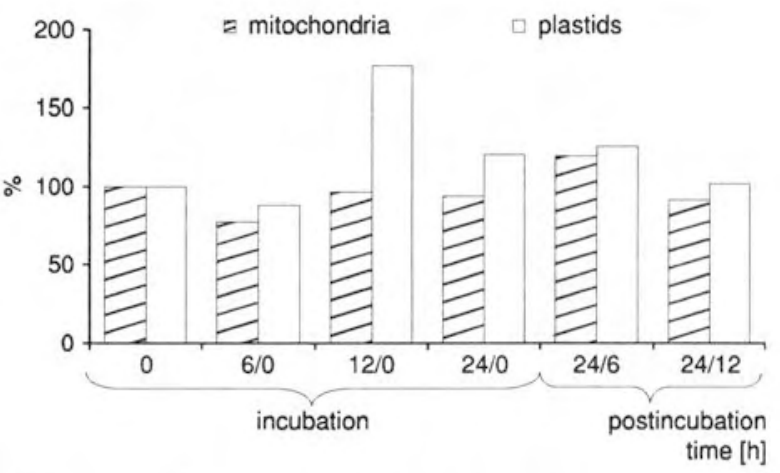

Fig. 3. Mean surface area of mitochondria and plastids on the cell cross-section during incubation in the TbE extract and postincubation in water, compared to control cells. Columns with different letters are significantly different.

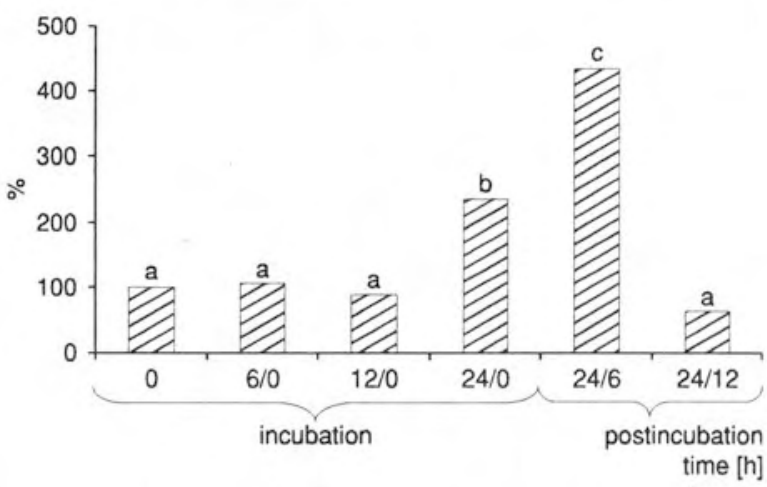

Fig. 4. Mean surface area of vacuoles on the cell cross-section during incubation in the TbE extract and postincubation in water, compared to control cells. Columns with different letters are significantly different. 




Fig. 5. Proportion (\%) of cell nuclei with condensed chromatin during incubation in the TbE extract and postincubation in water. Columns with different letters are significantly different.

The mean surface area of mitochondria in the initial period of incubation $(6 \mathrm{~h})$ decreased by $25 \%$ compared to control cells, while after $12 \mathrm{~h}$ it returned to the control status and remained at same level until $24 \mathrm{~h}$ of incubation (Fig. 3). In the initial period of postincubation $(6 \mathrm{~h})$, the surface area of mitochondria increased by $25 \%$ and after 12 $\mathrm{h}$ it fell slightly below the control level.

The mean surface area of plastids grew significantly $(\mathrm{p}<0.01)$ after $12 \mathrm{~h}$ of incubation (Fig. 3) as compared to the control. After $24 \mathrm{~h}$ of incubation the mean surface area of plastids fell by about $30 \%$ and it remained at that level until $6 \mathrm{~h}$ of postincubation, while after $12 \mathrm{~h}$ of postincubation it reached the control value (Fig. 3).

Increased vacuolization of study cells, as compared to control cells, was a characteristic response to the TbE treatment, manifested as the increased number (Fig. 2) and surface area of the vacuoles (Fig. 4) during incubation and postincubation. The highest vacuole counts were observed after $6 \mathrm{~h}$ of postincubation (Fig. 2), and the vacuole achieved the largest mean surface area after $24 \mathrm{~h}$ of incubation and after $6 \mathrm{~h}$ of postincubation (Fig. 4, 6C, 6D and 7B).

During incubation, the number of dictyosomes fell only slightly, while after $6 \mathrm{~h}$ of postincubation it rose nearly by half, as compared to controls (Fig. 2, Fig. 7D).

The alterations in the number and surface area of organelles were accompanied by changes in the ultrastructure of meristematic cells.

Following the treatment with the TbE extract, the proportion of the cell nuclei with condensed and dispersed chromatin changed (Fig. 5). In control cells, the nuclei with condensed chromatin accounted for $10 \%$ of all cell nuclei, while after 6 and $12 \mathrm{~h}$ of incubation in the TbE extract their percentage rose to $22 \%$ and $30 \%$ respectively (Fig. 5, $6 \mathrm{~A}$ and $\mathrm{B}, 8 \mathrm{C}$ ). After $24 \mathrm{~h}$ of incubation and during postincubation, the number of nuclei with condensed chromatin decreased significantly (p<0,01) (Fig. 5 and 6C). After 24 $\mathrm{h}$ of incubation and after $6 \mathrm{~h}$ of postincubation, the cell nuclei were often irregular in shape, had a markedly uneven surface and were pushed by very large vacuoles towards the cell wall (Fig. 6C, D and 7B).

Additionally, the TbE extract caused alterations in the ultrastructure of mitochondria and plastids. After 12 and 24 $\mathrm{h}$ of incubation in the TbE extract and after $6 \mathrm{~h}$ of postincubation some mitochondria were spherical in shape, the number of mitochondrial cristae was markedly reduced and there were lighter areas in the matrix (Fig. $6 \mathrm{~A}$ and $7 \mathrm{~B}, \mathrm{C}$ ).
In control cells mitochondria had a more electron-dense matrix and a lot of cristae (Fig. 8D). Plastids, after treatment of extract, had a considerably electron-dense stroma with lighter areas (Fig. 6B), which was not observed in control cells (Fig. 8D).

Changes in the cell ultrastructure also affected vacuoles, which demonstrated after $12 \mathrm{~h}$ of postincubation membranous and myelin structures as well electron-dense precipitates not found in controls (Figs 7E, D and 8A). Adjacent to the vacuoles numerous very active dictyosomes were found (Fig. 7D) as well as swollen and maturing cisternae of the smooth and rough endoplasmic reticulum (Figs 7D and 8B). Plasmalemma was at places uneven and 'interspaced' with exocytosomal vesicle (Fig. 8A).

Changes in ultrastructure concerned also MTs arrays. After $24 \mathrm{~h}$ of incubation the cytoskeleton was represented exclusively by cortical MTs, which were often accumulated on both sides of the irregularly thickened cell wall (Fig. 7A). Division MTs were not seen as cell divisions were inhibited at that time.

\section{Analysis of the tubulin cytoskeleton}

To analyse tubulin cytoskeleton, materials were collected after 6 and $12 \mathrm{~h}$ of incubation in the extract, when divisions of meristematic cells were still observed.

After incubation in the TbE extract alterations were seen in the MTs arrays, which concerned both interphase cells (cortical MTs and PPB formation), as well as cells in different phases of division (formation of the karyokinetic spindle and phragmoplast).

In most interphase cells, whose nuclei demonstrated dispersed chromatin, the parallel MTs array became disorganised. The MTs appeared torn, intersected at various angles and became bundled into larger aggregates, which demonstrated a more intense fluorescence (Fig. 9A, B) than in control cells, where the array was parallel (Fig. 9C, D).

In the cell nuclei, where chromosomal territories appeared (characteristic of cells entering from the G2 phase into mitosis, when a PPB is normally formed), the PPB formation was disturbed. It was often asymmetrically displaced or situated oblique in relation to the equatorial plane of the cell (Fig. 9E, F), as compared to its equatorial position in control cells (Fig. 9I, J). Occasionally double preprophase bands appeared in cells (Fig. 9G, H). At entering the stage of advanced prophase the PPB disappeared, while a normal karyokinetic spindle was not formed, in spite of the earlier formation of prophase and later metaphase chromosomes (Fig. 10A, B). At that stage, the MTs array was irregular, they were condensed and thickened (Fig. $10 \mathrm{~A}, \mathrm{~B}$ ) and formed 'baskets' not seen in control cells (Fig. 10C, D).

Some cells also demonstrated changes in the phragmoplast formation as its MTs were thickened with an irregular array (Fig. 10E, F), as compared to the regular MTs array in the phragmoplast of control cells (Fig. 10G, H).

All alterations produced by the TbE extract were transient and completely reversed after $8 \mathrm{~h}$ of postincubation.

\section{DISCUSSION}

So far there have been very few reports of the changes in the ultrastructure of cells treated with paclitaxel. That is why the aim of our study was to search for the reasons of 



Fig. 6. Ultrastructure of meristematic cells of A. cepa L. root tips in the course of incubation in the TbE extract (dilution 1:8). Ultrathin sections were stained with uranyl acetate and lead citrate (Transmission electron microscope, JEOL JEM 100C). Bar (6A-6D) $1 \mu$ m. A) 12-h incubation in the TbE extract; mitochondria reveal lighter areas in the matrix and a reduced number of mitochondrial cristae (arrows); a fragment of the cell nucleus with condensed chromatin (empty arrows); B) 12-h incubation in the TbE extract; elongated plastids with lighter areas in the stroma; the cell nucleus with condensed chromatin (arrows); C) 24-h incubation in the TbE extract; visible large vacuoles and smaller vacuoles fusing with larger ones (arrows); the cell nucleus with irregular surface and dispersed chromatin; D) 24-h incubation in the TbE extract. Organelles pushed into one region of the cell by large vacuoles, accumulation of elongated electron dense plastids (arrows), and the irregularly thickened and uneven cell wall.

Abbreviations used: CW - cell wall; D - dictyosom; M - mitochondrium; MTs - microtubules; N - nucleus; P - plastid; rER - rough endoplasmic reticulum; $\mathrm{V}$ - vacuole 

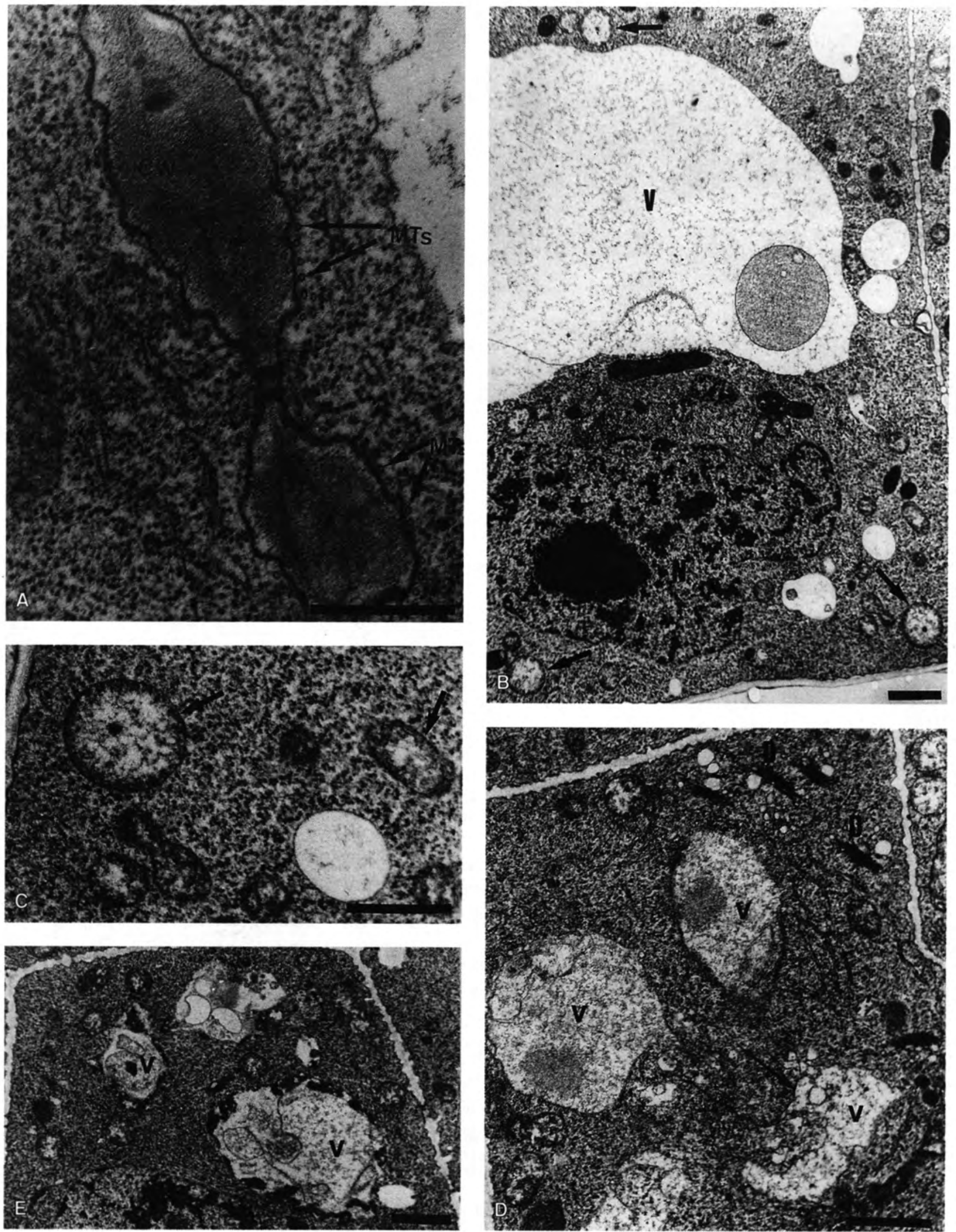

Fig. 7. Ultrastructure of meristematic cells of $A$. cepa L. root tips during incubation in the TbE extract (dilution 1:8) and postincubation in water. Ultrathin sections were stained with uranyl acetate and lead citrate (Transmission electron microscope, JEOL JEM 100C). A) 24-h incubation in the TbE extract; MTs (arrows) accumulated on both sides of the irregularly thickened cell wall. Bar $0.5 \mu \mathrm{m}$; B) 6-h postincubation; a large vacuole pushing the nucleus towards the cell periphery, spherical mitochondria with lighter areas in the matrix and reduced mitochondrial cristae (arrows), the nucleus with uneven surface. Bar $1 \mu \mathrm{m}$; C) 6-h postincubation; mitochondria with lighter areas in the matrix and reduced mitochondrial cristae (arrows). Bar $0.5 \mu \mathrm{m}$; D) 12-h postincubation; accumulation of active dictyosomes (with numerous vesicles), numerous vacuoles containing myelin structures, in their vicinity the ER swollen at the ends with emerging vesicles (arrow). Bar $1 \mu \mathrm{m}$; E) 12-h postincubation; vacuoles with electron-dense precipitates at the periphery. Bar $1 \mu \mathrm{m}$. 



Fig. 8. Ultrastructure of meristematic cells of A. cepa L. root tips in the course of postincubation in water. Ultrathin sections were stained with uranyl acetate and lead citrate (Transmission electron microscope, JEOL JEM 100C). A) 12-h postincubation; the large vacuole containing membranous structures, active maturing dictyosome and a large number of vesicles close to the plasmalemma which is uneven and interspaced with vesicles (arrows). Bar $1 \mu \mathrm{m}$; B) 12-h postincubation; Numerous dictyosomal vesicles and fragments of the rER cisterna undergoing fragmentation. Bar $0.5 \mu \mathrm{m} ; \mathrm{C}$ ) a fragment of the cell nucleus and active mitochondria and plastids in a control cell. Bar $1 \mu \mathrm{m}$; D) active mitochondria with numerous mitochondrial cristae and plastids in a control cell. Bar $0.5 \mu \mathrm{m}$. 

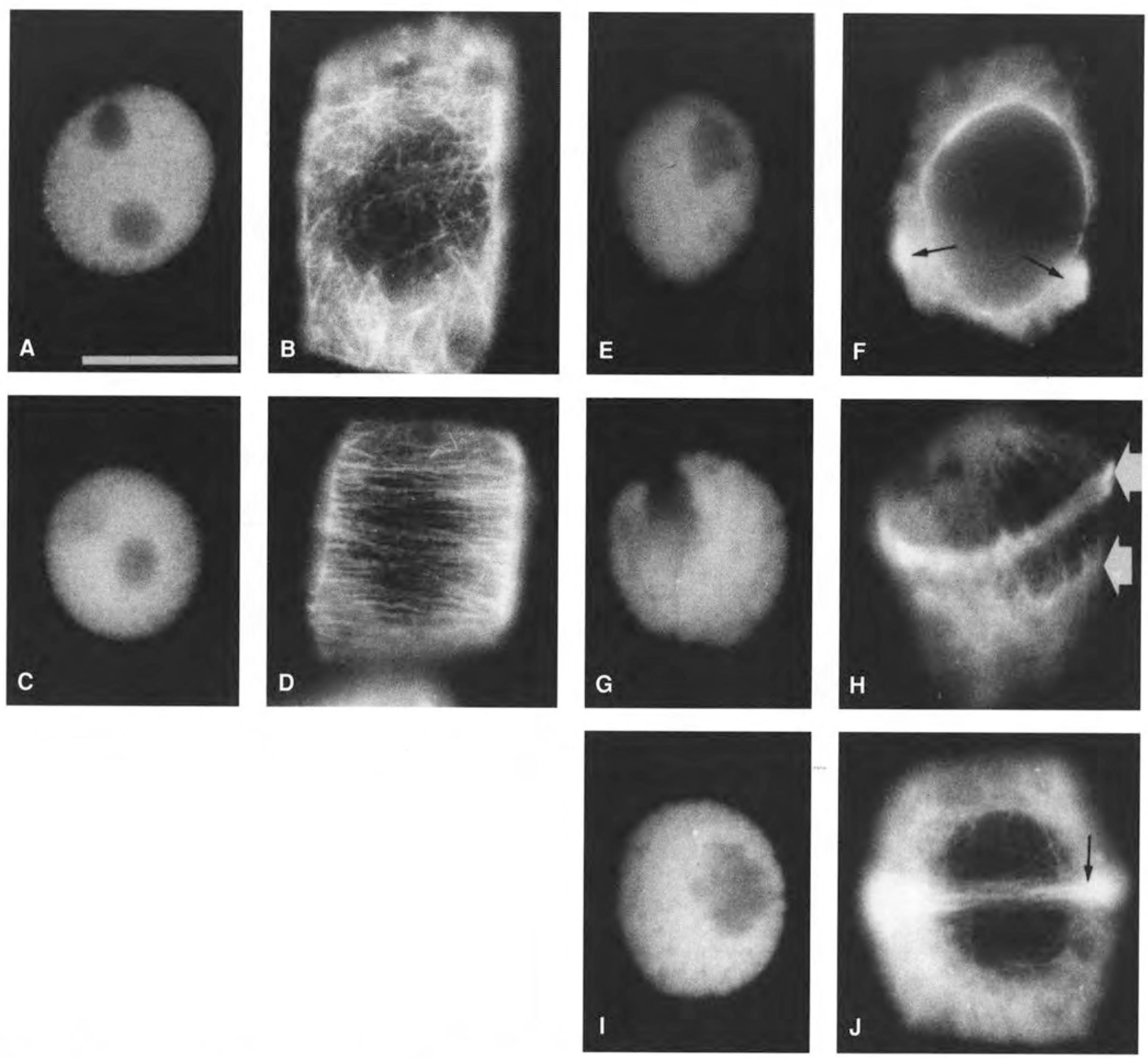

Fig. 9. Changes in the tubulin cytoskeleton of A. cepa L. cells after 6 and $12 \mathrm{~h}$ treatment with the TbE extract (dilution 1:8) correlated with the structure of the cell nuclei (A, B, E, F, G, H). The cytoskeleton and cell nuclei of control cells (C, D, I, J). Microtubules labeled with antibodies against $\alpha$-tubulin labeled with FITC, DNA stained with DAPI (Fluorescence microscope, Nikon). Bar (9A-9J) 20 $\mu$ m. A) the interphase cell nucleus with dispersed chromatin; B) irregular array of cortical MTs in an interphase cell; C) the interphase cell nucleus with dispersed chromatin in a control cell; D) ordered array of parallel cortical MTs in a control cell; E) and G) chromosomal territories in early-prophase cell nuclei; F) asymmetrical location of the PPB (arrows); H) a double preprophase band (thick arrows); I) the cell nucleus with emerging chromosome territories in a control cell; $J$ ) the preprophase band in the equatorial plane of the cell nucleus in a control cell (arrow).

toxic effects of paclitaxel at the level of plant cell ultrastructure. It is also important to explain whether the mode of action of paclitaxel in plant cells is similar to its effects on animal and human cells.

The most characteristic changes in the structure and ultrastructure of cells produced by the TbE extract, included decreased sizes of the cell nuclei and condensation of nuclear chromatin in the initial period of incubation with the subsequent reversal of the changes after $24 \mathrm{~h}$. Also characteristic and undoubtedly related to the treatment were alterations in the number and surface area of mitochondria and plastids, their partial degradation as well as increased cell vacuolisation and irregular thickening of the cell wall as a result of MTs accumulation.

A decrease in size of the cell nuclei and chromatin condensation in the initial period of incubation with the reversal of the changes after $24 \mathrm{~h}$, were earlier observed by Baluška et al. (1997) in maize root meristematic cells treated with Taxol ${ }^{\circledR}$. In our study, a decrease in size of cell nuclei after $12 \mathrm{~h}$ of incubation in the $\mathrm{TbE}$ extract was related to chromatin condensation, and thus the reduced transcriptional activity in response to stress. It is also possible that it was due to MTs disorganisation, as it is likely that MTs affect the regulation of chromatic structure and the course of 

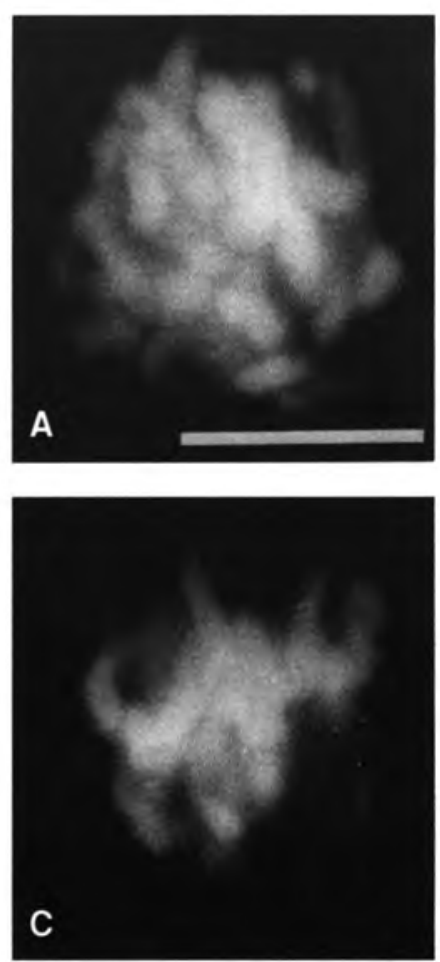


Fig. 10. Changes in the tubulin cytoskeleton of A. cepa L. cells after 6 and $12 \mathrm{~h}$ treatment with the TbE extract (dilution 1:8) correlated with the structure of the chromosomes (A, B, E, F). The cytoskeleton and chromosomes of control cells (C, D, G, H). Microtubules treated with antibodies against $\alpha$-tubulin stained with FITC, DNA stained with DAPI (Fluorescence microscope, Nikon). Bar (9A-9J) 20 $\mu$ m. A) irregular array of metaphase chromosomes; B) microtubules forming a 'basket' wound around metaphase chromosomes. Arrows indicate closely assembled MTs; C) regular metaphase array of chromosomes in the equatorial plate in a control cell; D) regular polar and kinetochore MTs forming the karyokinetic spindle in a control cell; E) telophase chromosomes; F) regular MTs array in the phragmoplast at the centre where the middle lamella is formed and an irregular MTs array on both sides of the phragmoplast (arrows); G) telophase chromosomes in a control cell; H) phragmoplast formed of MTs perpendicular to the equatorial plane (aster).

the cell cycle in both maize root tip cells (Baluška and Barlow 1993; Baluška et al. 1995a, 1997) and of meristematic cells of $A$. cepa roots.

On the other hand, it is probable that the increased sizes of the cell nuclei after $24 \mathrm{~h}$ of incubation were related to the decondensation of chromatin in the nuclei arrested in the G2/M phase of the cell division cycle (Majewska et al 2000). This decondensation may have also resulted from disorganisation of the microtubules treated with the $\mathrm{TbE}$ extract as MTs disorganisation causes activation of protein kinases (Shinohara-Gotoh et al. 1991; Nishida and Gotoh 1992) and decondensation of nuclear chromatin (Baluška and Barlow 1995b). This effect is associated with increased level of cytoplasmatic calcium as a typical response to various stressful factors (Baluška et al. 1997).

During the incubation in the TbE extract, the number of mitochondria and plastids decreased. Most probably that was due to the degradation of these organelles with the simultaneous inhibition of their divisions. The considerable increase in the mean surface area of plastids after $12 \mathrm{~h}$ of incubation, may also indicate that their divisions were inhibited, which would correlate with the inhibition of cell divisions, demonstrated in our earlier study (Majewska et al. 2000).

The degradation of mitochondria and plastids was also confirmed by their ultrastructure with a decreased number of membranous structures and lighter areas in their matrix. Such changes have been often observed as a result of action of toxic agents (Lemasters et al. 1997). A similar de- gradation of mitochondria was observed by Lux (1984) in a study of the ontogenesis of xylem cells in barley roots, and by Farbos (2001) in a study of the floral meristem of male sterile plants of Nicotiana tabacum. Additionally, it is possible that disorders in the ultrastructure and function of mitochondria, produced by reduced metabolic activity, were an indirect result of the nuclear chromatin condensation. Over $95 \%$ of mitochondrial proteins, which are responsible for electron transport, ATP synthesis and mitochondrial genome expression, is encoded by the nuclear genome (De Paepe et al. 1990; Paschen and Neupert 2001). Degradation of a larger number of mitochondria during incubation in the TbE extract may have in turn led to reduce cell metabolism as a result of a decrease in cellular ATP (Bergman et al. 2000).

During postincubation, the number of mitochondria and plastids markedly increased, which was associated with a general activation of living processes at that time, correlated with the resumption of cell divisions.

During incubation in the TbE extract and postincubation the cell vacuolisation increased. Various membranous and myelin structures and electron-dense precipitates appeared in the vacuole. These findings were associated with the presence of very active dictyosomes with a large number of vesicles, as well as swollen and maturing cisternae of the smooth and rough endoplasmic reticulum. These changes were due to the cell detoxification and the autolysis of organelles degraded during incubation. It is known that va- 
cuolar or secretory proteins are synthesised in the endoplasmic reticulum (Tormakangas et al. 2001). These proteins play a role in lysis while many of them may additionally participate in defensive responses. One function of dictyosomes is also to detoxify the cell. A very large number of dictyosomal vesicles was found just at the plasmalemma or through the plasmalemma, possessing markedly uneven surface, they were incorporated into the cell wall, confirming the considerable transport related to secretion or excretion.

The uneven distribution of MTs at the cell wall, producing its irregular thickening at the site of MTs accumulation, was a very characteristic change in the ultrastructure of cells treated with the TbE extract. This was probably related to the stabilisation of MTs, which tended to aggregate into larger formations, which prevented normal orientation of cellulose microfibrils in the cell wall (Baskin 2001).

Our immuonocytochemical assays demonstrated, that the TbE extract disturbed all MTs arrays in the meristematic cells of A. cepa. In the interphase cells, also the parallel array of cortical MTs became disturbed as they were torn, criss-crossed and densely packed into larger aggregates. Paclitaxel is known to stabilise MTs by their increased formation with the resulting decrease in the pool of free tubulin in the cytoplasm (Rowinsky et al. 1988). As the tubulin concentration fell below the critical level, it prevented the formation of cortical MTs with the resulting disturbances in the formation of the cortical cytoskeleton, its incompleteness and disordered alignment.

Also disorders in the formation of the PPB were observed, such as its asymmetrical array or a double PPB, which may have resulted from earlier changes in the cortical skeleton, as cortical MTs are known to participate in the formation of the PPB (McCurdy and Gunning 1990). Other reasons may include stabilisation of the MTs and their abnormal array.

Also, the characteristic array of MTs resembling 'baskets' instead of a normal karyokinetic spindle, following the $\mathrm{TbE}$ treatment, may have been due to changes in MTs reorganisation at the stage when the PPB is transformed into the karyokinetic spindle. Published studies confirm that the spindle is formed when MTs included in the PPB are reorganised (McCurdy and Gunning 1990). That is why the MTs stabilisation at the time when the spindle was formed from the PPB, caused the condensation and thickening of the MTs, which demonstrated the cytoskeleton organisation, which was very unusual for this phase of the cell division cycle.

The results of our studies demonstrate that the mechanism of action on plant cells of the TbE extract containing paclitaxel is the same as the mechanism of paclitaxel action on animal and human cells. By producing changes in the cytoskeleton (MTs stabilisation) it affects the accumulation of cells in the phase G2/M of the cell cycle and inhibits cell divisions (Majewska et al. 2000). However, disturbances in the array of microtubules in plant cells were somehow different from those seen in animal and human cells. In animal and human cells paclitaxel typically produced bundles and asters (Schiff and Horwitz 1980), which led to apoptosis via the inhibition of mitotic processes. Yet apoptosis did not occur in our experimental system.

Apart from the above, an important aim of this study was to investigate whether the cytotoxicity of the TbE extract was reflected in the ultrastructure of plant cells. The results indicate changes in the ultrastructure, while the partial degradation of the ultrastructural organisation of mitochondria and plastids may produce the altered energetic status of the cell.

Additionally, changes in the chromatic condensation may be related to both the decreased transcriptional activity (chromatin condensation) and the MTs disorganisation (chromatin decondensation). With the used TbE extract concentration, changes in the cell ultrastructure were not serious enough to produce their permanent damage, as proved by the return of a normal cell structure after longer postincubation.

Considering low toxicity of the $\mathrm{TbE}$ extract, confirmed by the absence of chromosomal aberrations and micronuclei (Majewska et al. 2000), as compared to the effects of pure paclitaxel, combined with the same cytostatic effects as those of the drug, one may assume that the use of the TbE extract might be helpful in antitumor therapy. This would require determining the contents of other taxoids apart from paclitaxel, which is planned in our further studies.

\section{LITERATURE CITED}

BALUŠKA F. AND BARLOW P.W. 1993. The role of the microtubular cytoskeleton in determining nuclear chromatin structure and passage of maize root cells through the cell cycle. Eur. J. Cell. Biol. 61: 160-167.

BALUŠKA F., BACIGALOWA K., OUD J.L., HAUSKRECHT M., KUBICA Ś. 1995a. Rapid reorganization of microtubular cytoskeleton accompanies early changes in nuclear ploidy and chromatin structure in postmitotic cells of barley leaves infected with powdery mildew. Protoplasma 185: 140-151.

BALUŠKA F., BARLOW P.W., HAUSKRECHT M., KUBICA Ś., PARKER J. S., VOLKMANN D. 1995b. Microtubull arrays in maize root cells. Interplay between the cytoskeleton, nuclear organization and post-mitotic cellular growth patterns. New Phytol. 130: 177-192.

BALUŠKA F., ŠAMAJ J., VOLKMANN D., BARLOW P. 1997. Impact of taxol-mediated stabilisation of microtubules on nuclear, ploidy levels and cell growth in maize roots. Biol. Cell. 89: 221-231.

BASKIN T.I. 2001. On the alignment of cellulose microfibrils by cortical microtubules: review and a model. Protoplasma 215: 150-171.

BERGMAN P., EDQVIST J., FARBOS I., GLIMELIUS K. 2000. Male sterile tobacco display abnormal mitochondrial atp1 transcript accumulation and reduced floral ATP/ADP ratio. Plant Mol. Biol. 42: 531-544.

COLLINGS D., ASADA T., ALLEN N., SHIBAOKA H. 1998. Plasma membrane-associated actin in Bright Yellow 2 tobacco cells. Plant Physiol. 118: 917-928.

DE PAEPE R., CHETRIT P., VITART V., AMBARD-BRETTEVILLE F., PRAT D., VEDEL F. 1990. Several nuclear genes control both male sterility and mitochondrial protein synthesis in Nicotiana sylvestris protoclones. Mol. Gen. Genet. 222: 206-210.

FARBOS I., MOURAS A., BERETERBIDE A., GLIMELIUS K. 2001. Defective cell proliferation in the floral meristem of alloplamic plants of Nicotiana tabacum leads to abnormal floral organ development and male sterility. Plant J. 26(2): 131-142.

HALDAR S., CHINTAPALLI J., CROCE C.M. 1996. Taxol-induced bcl-2 phosphorylation. Cancer Res. 56: 1253-1255.

LEMASTERS J., NIEMINEN A., QIAN T., TROST L., HERMAN B. 1997. The mitochondrial permeability transition in toxic, hypoxic and reperfusion injury. Mol. Cell. Biochem. 174: $159-165$. 
LONG B.H., FAIRCHILD C.R. 1994. Paclitaxel inhibits progression of mitotic cells to G1 phase by interference with spindle formation without affecting other microtubull functions during anaphase and telophase. Cancer Res. 54: 4355-4361.

LUX A. 1984. Ontogenesis of xylem cells in barley roots III. Vacuolization and autolysis. Acta F R N Univ Comen - Physiologia Plantarum 20: 7-18.

MACCURDY D., GUNNING E. 1990. Reorganization of cortical actin mikrofilaments and microtubules at preprophase and mitosis in wheat root-tip cells: a double label immunofluorescence study. Cell. Motil. Cytoskeleton 15: 76-87.

MAJEWSKA A., FURMANOWA M., ŚLIWIŃSKA E., GLOWNIAK K., GUZEWSKA J., KURAŚ M. ZOBEL A. 2000. Influence of extract from shoots of Taxus baccata var. Elegantissima on mitotic activity of meristematic cells of Allium cepa L. roots. Acta Soc. Bot. Pol. 69: 185-192.

MOORTELE S., PICART R.., TIXIER-VIDAL A., TOUGARD C. 1992. Nocodazol and taxol affect subcellular compartments but not secretory activity of GH3B6 prolactin cells. Eur. J. Cell. Biol. 60: 217-227.

NISHIDA E., GOTOH Y. 1992. Mitogen - activated protein kinase and cytoskeleton in mitogenic signal transdiction. Int. Rev. Cytol. 138: 211-238.

PASCHEN S., NEUPERT W. 2001. Protein import into mitochondria. IUBMB Life 52: 101-12.

PIETROSIUK A., FURMANOWA M., ZOBEL A., KURAŚ M., MICHALAK A. 1999. Cytological changes in meristematic cells of Allium cepa L. root tips treated with extracts from callus of Catharanthus roseus (L.). Acta Soc. Bot. Pol. 68: 109-118.

RAINEY W.E., KRAMER R.E., MASON J.I., SHAY J.W. 1985. The effect of taxol, a microtubule-stabilizing drug, on steroidogenic cells J. Cell. Physiol. 123: 17-24.

RAO S., KRAUSS N.E., HEERDING J.M., SWINDELL C.S., RINGEL I., ORR G.A., HORWITZ S.B. 1994. 3'-p. (Azidobenzamido) Taxol photolabels the $N$ terminal 31aa of $\beta$ tubulin. J. Biol. Chem. 269: 3132-3134.
REYNOLDS E.S. 1963. The use of lead citrate at high $\mathrm{pH}$ as electron-opaque stain for electron microscopy. J. Cell. Biol. 17: 208-213.

ROWINSKY E.K., DONEHOWER R.C., JONES R.J., TUCKER R.W. 1988. Microtubule Changes and Cytotoxicity in Leukemic Cell Lines Treated with Taxol. Cancer Res. 48: 40934100 .

ROWINSKY E.K., EISENHAUER E.A., CHAUDHRY V. 1993. Clinical toxicities encountered with paclitaxel (Taxol). Semin. Oncol. (Suppl. 3), 20: 1-16.

SCHIFF P.B., HORWITZ S.B. 1980. Taxol stabilizes microtubules in mouse fibroblast cells. Proc. Natl. Acad. Sci. USA 3: 1561-1565.

SHINOHARA-GOTOH Y., NISHIDA E., HOSHI M., SAKAI H. 1991. Activation of microtubule-associated protein kinase by microtubule disruption in quiescent rat 3Y1 cells. Exp. Cell. Res. 193: 161-166.

THEODOROPOULOS P., POLIOUDAKI H., KOSTAKI O., DERDAS S., GEORGOULIAS V., DARGEMONT C., GEORGATOS S. 1999. Taxol affects nuclear lamina and pore complex organization and inhibits import of karyophilic proteins into the cell nucleus. Cancer Res. 59: 4625-4633.

TORMAKANGAS K., HADLINGTON J.L., PIMPL P., HILLMER S., BRANDIZZI F., TEERI T.H., DENECKE J. 2001. A vacuolar sorting domain may also influence the way in which proteins leave the endoplasmic reticulum. Plant Cell. 13: 2021-2032.

WANI C., TAYLOR H.L., WALL M.E. 1971. Plant antitumor agents VI. The isolation and structure of taxol, a novel antileukemic and antitumor agent from Taxus brevifolia. J. Am. Chem. Soc. 93: 2325-2327.

ZHANG H.Q., LI Y.Q., KURAŚ M., BEDNARA J., CRESTI M. 1996. Influence of hydroxyurea on cell divisions and microtubular cytoskeleton in Allium cepa root merystem. Acta Soc. Bot. Pol. 65: 179-185.

\section{WPŁYW EKSTRAKTU Z PĘDÓW TAXUS BACCATA VAR. ELEGANTISSIMA NA ULTRASTRUKTURE, I CYTOSZKIELET TUBULINOWY KOMÓREK MERYSTEMATYCZNYCH WIERZCHOŁKA KORZENIA ALLIUM CEPA L.}

\section{STRESZCZENIE}

Badano działanie ekstraktu z pędów Taxus baccata var. Elegantissima (TbE) w rozcieńczeniu 1:8, zawierającego paklitaksel w stężeniu $81,6 \mu \mathrm{g} / \mathrm{g}$ świeżej masy na ultrastrukturę i cytoszkielet tubulinowy komórek merystematycznych wierzchołków korzeni Allium cepa $\mathrm{L}$.

Po 3, 6, 12 i 24 godz. inkubacji w ekstrakcie przeprowadzono 12 i 24 godz. postinkubację w wodzie. W trakcie krótkiej inkubacji (do 12 godz.) zmniejszyła się powierzchnia jąder komórkowych i doszło do kondensacji chromatyny (w porównaniu do kontroli) natomiast po $24 \mathrm{~h}$ inkubacji średnia powierzchnia jąder wzrosła, a ich chromatyna uległa dekondensacji. Po działaniu ekstraktu zwiększyła się powierzchnia plastydów i wakuol. Ponadto w trakcie inkubacji wystąpiły zmiany w ultrastrukturze mitochondriów i plastydów, które ustąpiły po 12 godz. postinkubacji.

Badania immunocytochemiczne wykazały, że w trakcie inkubacji w ekstrakcie z TbE doszło do częściowej dezorganizacji cytoszkieletu tubulinowego. W większości komórek interfazowych mikrotubule (MTs) kortikalne zatraciły swoją równoległą orientację. Preprofazowy pierścień (PPB) często wykazywał asymetryczne położenie w komórce. Zakłóceniu ulegał także układ MTs wrzeciona kariokinetycznego i fragmoplastu. Zmiany te jednak całkowicie ustępowały w postikubacji.

SŁOWA KLUCZOWE: Taxus baccata var. Elegantissima, ekstrakt, paklitaksel, ultrastruktura, tubulinowy cytoszkielet. 